\title{
The Behavior of Multi-Story Buildings Seismically Isolated System Hybrid Isolation (Friction, Rubber and with the Addition of Rotational Friction Dampers)*
}

\author{
Alaa Barmo1, Imad H. Mualla², Hala T. Hasan1 \\ ${ }^{1}$ Department of Structural Engineering, Higher Institute of Seismic Research and Studies, University of \\ Damascus, Damascus, Syria \\ ${ }^{2}$ DAMPTECH, Ltd, Technical University of Denmark, Lyngby, Denmark \\ Email: engalaabarmo@yahoo.com
}

Received 29 October 2014; revised 27 November 2014; accepted 15 December 2014

Copyright (C) 2015 by authors and Scientific Research Publishing Inc.

This work is licensed under the Creative Commons Attribution International License (CC BY).

http://creativecommons.org/licenses/by/4.0/

(c) (i) Open Access

\section{Abstract}

Increasing buildings' resistance to earthquake forces is not always a desirable solution especially for the building contents that are irreplaceable or simply more valuable than the actual primary structure (e.g. museums, data storage Centre's, etc.). Base isolation and seismic dampers can be employed to minimize inter-story drifts and floor accelerations via specially designed isolation and dampers system at the structural base, or at higher levels of the superstructure. In this research, we'll examine the response of buildings isolated using isolation system hybrid consisting of Lead-Rubber Bearings (LRB), Flat Sliding Bearings (FSB), with the addition of Rotation Fiction Damper (FD) at the base, then compare the results with buildings that have traditional foundation, in terms of the (period, displacement and distribution shear force and height of the building). It conducts TIME HISTORY seismic analysis for some varying height buildings (eight, twelve, sixteen, and twenty stories), with help of SAP2000 using an earthquake acceleration-time history for (EICentro). The results show that the use of insulation system Hybrid has had a significant impact on improving the performance of origin in terms of reducing displacements and base shear with increasing height of the building, but has had a negative impact on the drift, which leads to an increase in drift with the increased flexibility of the building.

*This research was prepared in the context of a Master Engineer Alaa Barmo under the supervision of Dr. Hala Hassan and the participation of Dr. Imad Mualla 


\section{Keywords}

\section{Seismic Isolation, Basement Isolation, Response of Buildings, The Passive Control, Damping, Drift}

\section{Introduction}

The traditional design principle of the earthquake resistant structures is that each element of the structure is able to resist the applied seismic forces with enough plasticity to absorb vibration energy caused by the earthquake. In this case, you get a large plastic deformation in the structural elements that are difficult to repair and restore after the earthquake and might develop to an irreparable structure [1]-[10].

Therefore, the uses of the seismic isolation system in these structures have a major positive role for these buildings resistant to earthquakes [1].

The seismic isolation method is a creative seismic design method intended to protect the structure against the seismic risk and reduce the seismic energy and forces that structure suffer and not directly resist those forces [1]-[11]. The importance of seismic isolation comes from its flexibility that increases the vibration period of the total structure of the basic structure and isolation system [10]. Although flexibility increase of the total structure increases its displacement, it's possible to reduce its displacement by damping increase through adding seismic dampers to seismic isolators [4].

\section{The Techniques and Principles of Seismic Isolation}

Traditional structure without isolating seismic suffers important floor offsets during earthquakes, which could lead to the structure collapse. While isolated structure vibrates as a solid body by large deformation at the base, (Figure 1): a comparison between the behavior of the isolated structure and fixed base structure under the influence of an earthquake (the isolated structure applied side force not reduced, but redistributed over the entire height of the structure [1] [11].

Characteristics of Well-Designed Seismic Isolation Systems (Figure 2) [11]:

- Flexibility to increase period of vibration and thus reduce force response (Figure 2(a)).

- Energy dissipation to control the isolation system displacement (Figure 2(b)).

Rigidity under low load levels such as wind and minor earthquakes.

\section{Types of Seismic Isolation Bearings and Dampers [1] [11]}

The success of any seismic isolation system structure mainly on the quality of the bearings used in the system,

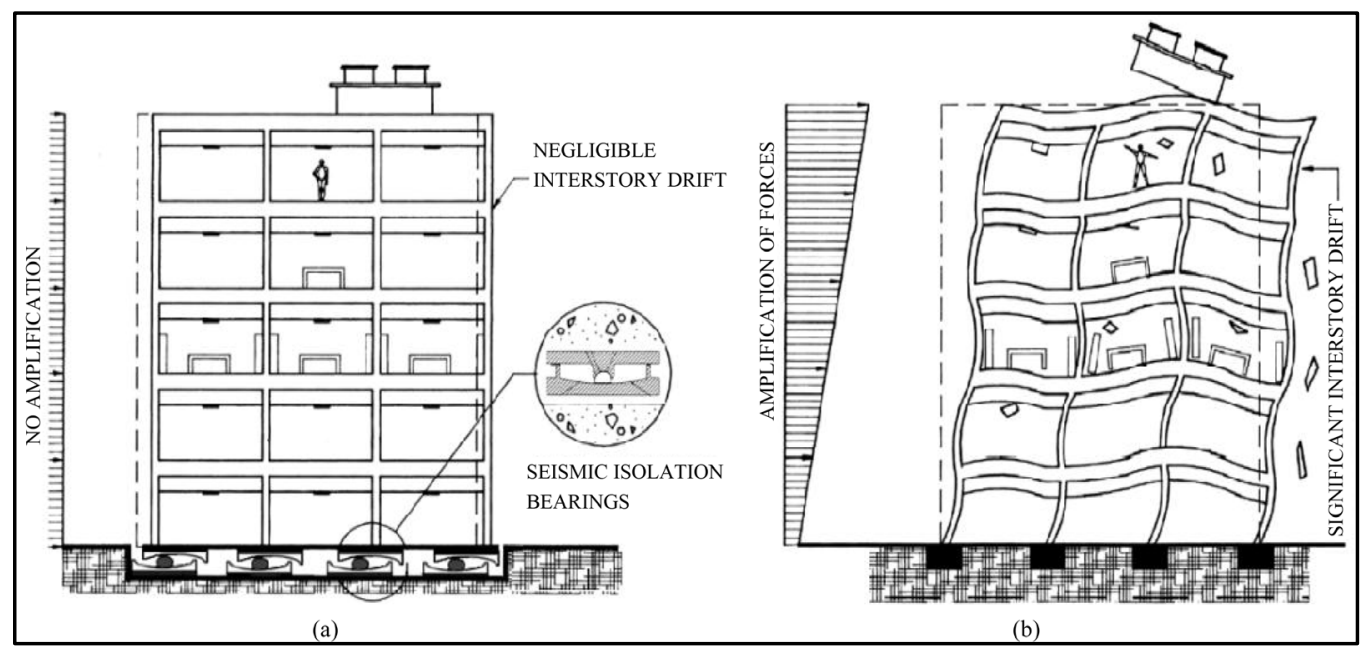

Figure 1. (a) Isolated structure; (b) Reliable structure with its foundations [1]. 


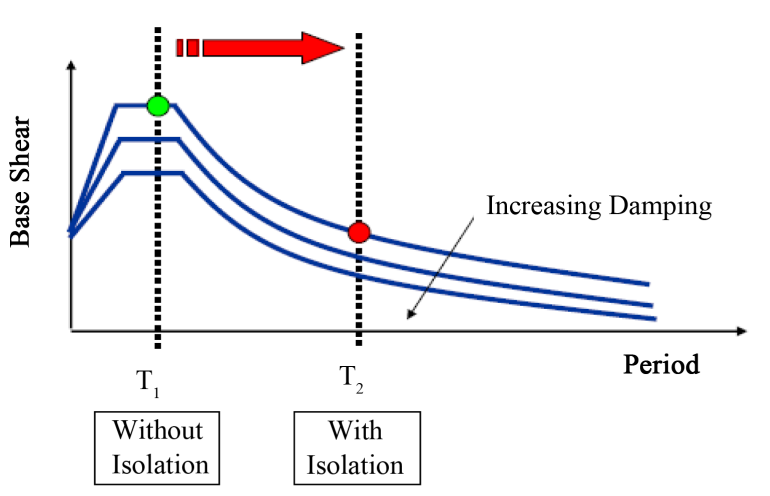

(a)

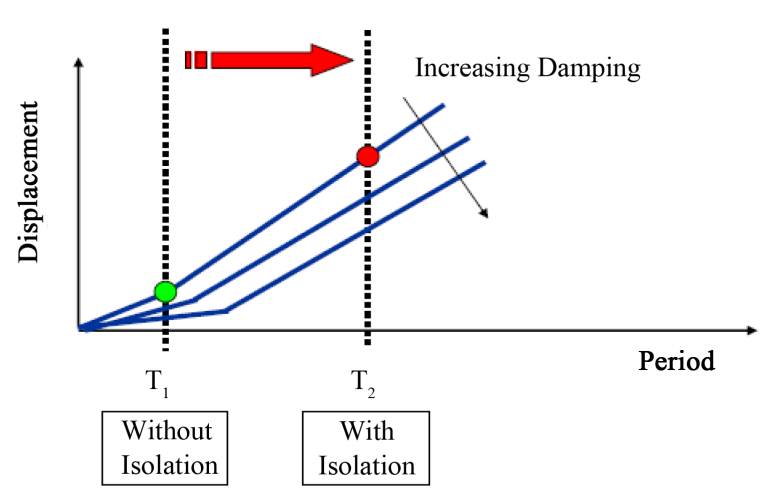

(b)

Figure 2. (a) Effect of increase period of vibration of structure to reduce base shear; (b) Increase of period increases displacement demand (now concentrated at base) [11].

which is supposed to provide flexibility horizontal and damping required in addition to the return of power.

The modern seismic isolation systems for the base are classified into two categories [11]:

$\checkmark$ Electrometric bearing system (Figure 3).

$\checkmark$ Bearing systems sliding (Figures 4-5).

\subsection{Elastomeric Bearing System [11]}

Of the most important rubber bearings used in isolation structures are rubber bearings low or high damping or low damping natural rubber with lead core (LRB) [1]-[15].

\section{Lead-Rubber Bearing (LRB) [2]-[15]}

Is based on lead-core generate hysterical damping and hence power dissipation, also depends on the rubber in the generation of forces returns (Figure 3).

\subsection{Sliding Bearing System [11]}

Based system for power dissipation on the friction generated between the composite material which usually consists of high strength material soily or gummy known as "PTFE" (poly tetra fluoro ethylene), and sliding surfaces of steel (stainless steel) (Figures 4-5).

Insulation systems are classified slider turn into two types: [8]

- Spherical Sliding Bearing (Figure 4).

- Pure friction system (Figure 5).

Proven experience and expertise previous that slider isolation systems, which rely horizontal sliding surfaces (Figure 5) cause large residual transitions in the structure because of the absence of mechanical forces return, so is the need for additional devices to Insurance Returns forces [11]. The insulation system that takes slider sliding surface (Figure 4) which form concave and thus secures a waste of energy, mechanical and return to the center after the excitement in the seismic isolation unit [1]-[8] [11].

Recall of these systems:

\subsubsection{Friction Pendulum System (FPS) [1]-[8] [11]}

Is the frictional insulation system depends on the geometric shape and the forces of gravity in prolonging natural vibration period of the isolated structure and ingenerates returns the mechanics, and thus face seismic forces with high wrenches (Figure 4).

\subsubsection{Flat Sliding Bearing (FSB) [11]}

Sliding bearings provide an elastic-perfectly plastic hysteresis shape with no strain hardening after the applied force exceeds the coefficient of friction times the applied vertical load (Figure 5). This is attractive from a structural design perspective as the total base shear on the structure is limited to the sliding force. 


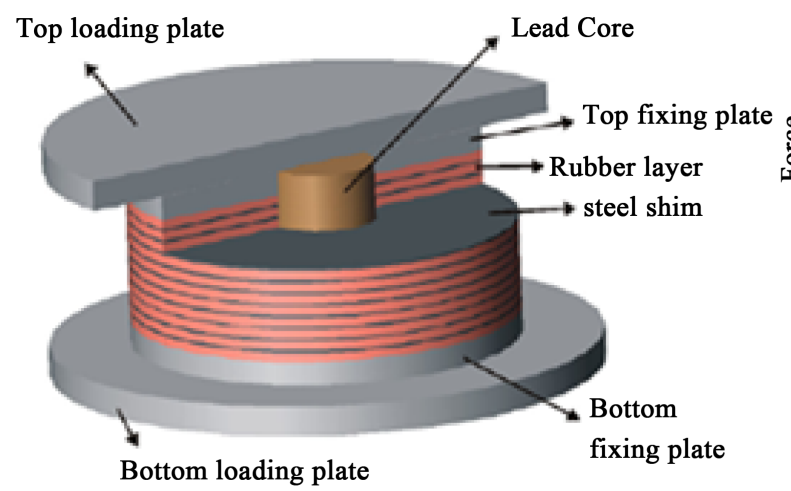

(a)

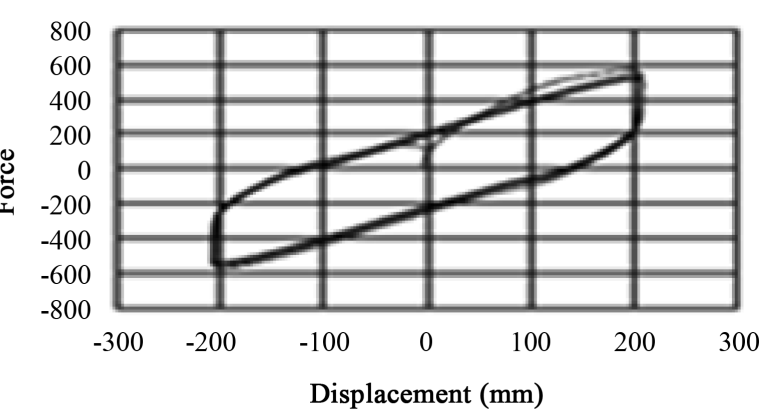

Hysteresis Loop of a LRB

(b)

Figure 3. LPB isolator: (a) Components; (b) Hysteresis loop of a LPB [15] [16].

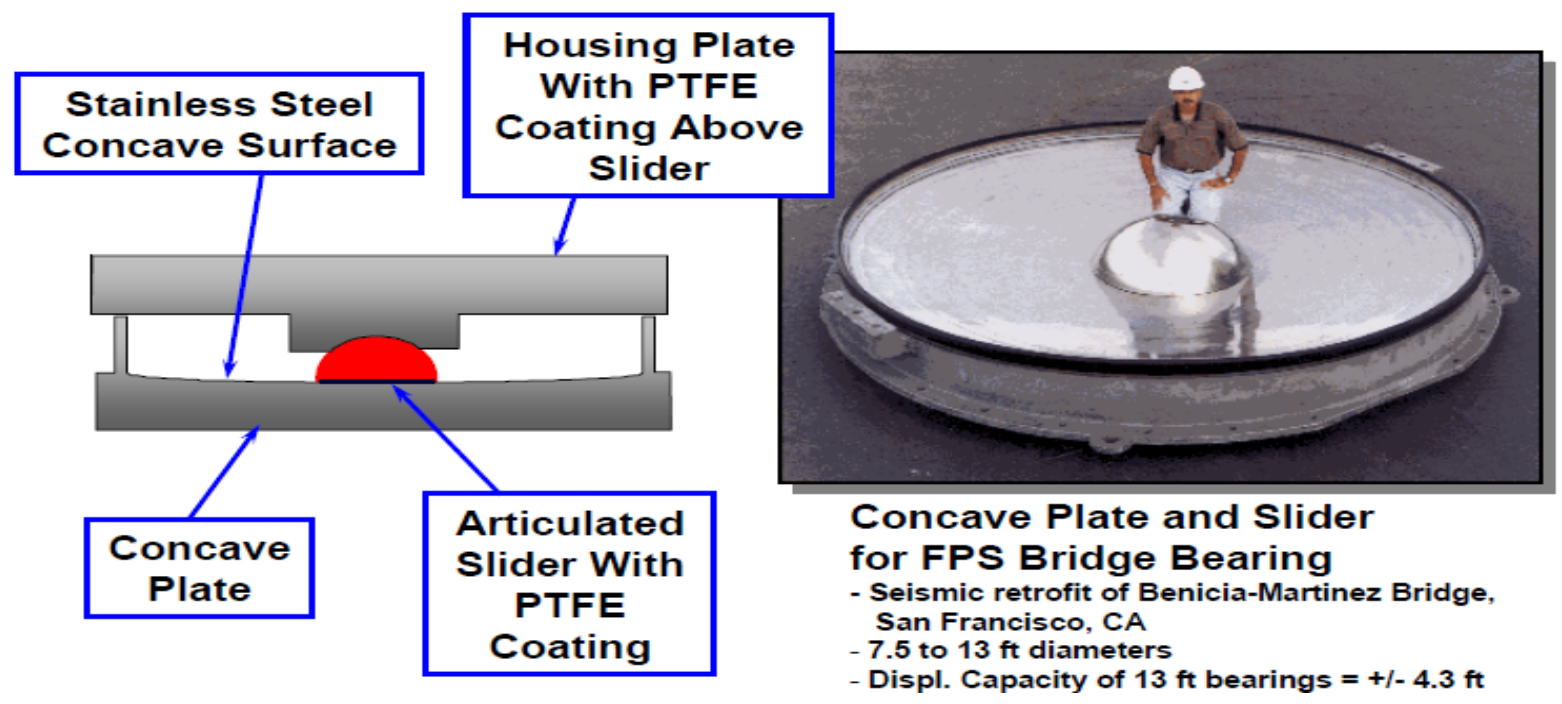

Figure 4. Friction pendulum and its components [11].
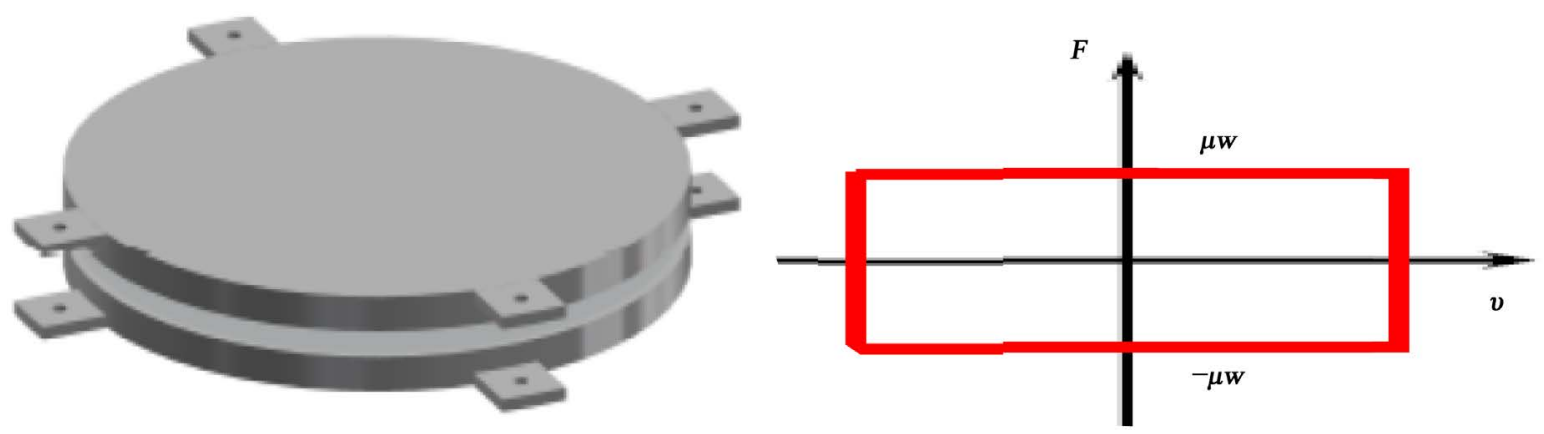

Figure 5. Hysteresis loop of flat sliding [11].

In practice, sliding bearings are not used as the sole isolation component for two reasons [1] [11]:

1) Displacements are unconstrained because of the lack of any centering force. The response will tend to have a bias in one direction and a structure on a sliding system would continue to move in the same direction as earthquake aftershocks occur [11].

2) A friction bearing will be likely to require a larger force to initiate sliding than the force required to maintain sliding. This is termed static friction, or "stickion". If the sliders are the only component then this initial 
static friction at zero displacement will produce the governing design force [11].

\subsection{Seismic Dampers [4]}

Although the devices isolation seismic are manufactured typically with the ability to dissipate the energy and control to max move for device isolation, but there are situations we need to complementary mechanisms of the insulation system (dampers) to dissipate energy and to reduce the displacements [4],

Some of these cases [4]:

-The location is close to seismic source dominant.

-To be under the soil layers insulation systems of tor weak.

-The isolation devices are prone to instability in the light both sides of the large deformation.

-Architectural considerations that limit the seismic interval allowed.

-The practical limitstostructureservicesandtheirtowithstandgreatmoveforisolationsystem.

\subsection{Some Types of Dampers}

\subsubsection{Rotation Friction Dampers (FD) [4]}

-This device is designed to dissipate seismic energy and protect buildings from structural and structural damage during earthquakes moderate and severe (Figure 6).

-The damper has been tested at DTU in Denmark and later on experimental tests have also been carried out with the pure friction damper at Takenaka research center in Japan. The comparison of results obtained from the experimental and numerical models shows good agreement [4].

-Also uses rotational friction damper (FD) with other insulation systems such as (LRB) or (FPS) and others, as complementary dampers to control the Insulation deformation, and also for the formation of a hybrid insulation systems.

-The numerical studies have demonstrated that the overall response is mainly affected by damper properties as geometry, frictional sliding moment and viscoelastic properties combined with the structural natural frequencies [4].

-The device is easy to manufacture and implement in structures (Figure 6). It is an economic device due to material availability. It can easily be replaced if damaged, which is unlikely, and it can easily be readjusted after use [4].

\subsubsection{Damper Friction Which Is Used to Solve the Problem of the Nearby Distance between} Buildings [4]

Types of dampers, friction dampers which are used to solve the problem of the nearby distance between buildings (Figure 7).

\subsubsection{Viscous Dampers VD [8]}

This also added to the insulation system as supplemental to control on the displacement (Figure 8).

\section{Objective of This Research}

-Study the effect of basement isolation system hybrid (LRB + FSB) on the response of isolated structures.

-Study combined effect the seismic isolation system hybrid (FSB, LRB) with rotational friction damper (FD) and its impact on structure response.

\section{Modelling of Dampers and Isolator}

\subsection{Linear Mathematical Model for Natural Rubber Bearings (NRP) [1]-[15]}

Shows in Figure 9 the modeling for natural rubber bearings and the relationship between the force and the displacement.

$K_{\text {eff }}=$ Effective stiffness at design displacement.

$C_{\text {eff }}=$ Effective damping coefficient Associated with design displacement. 

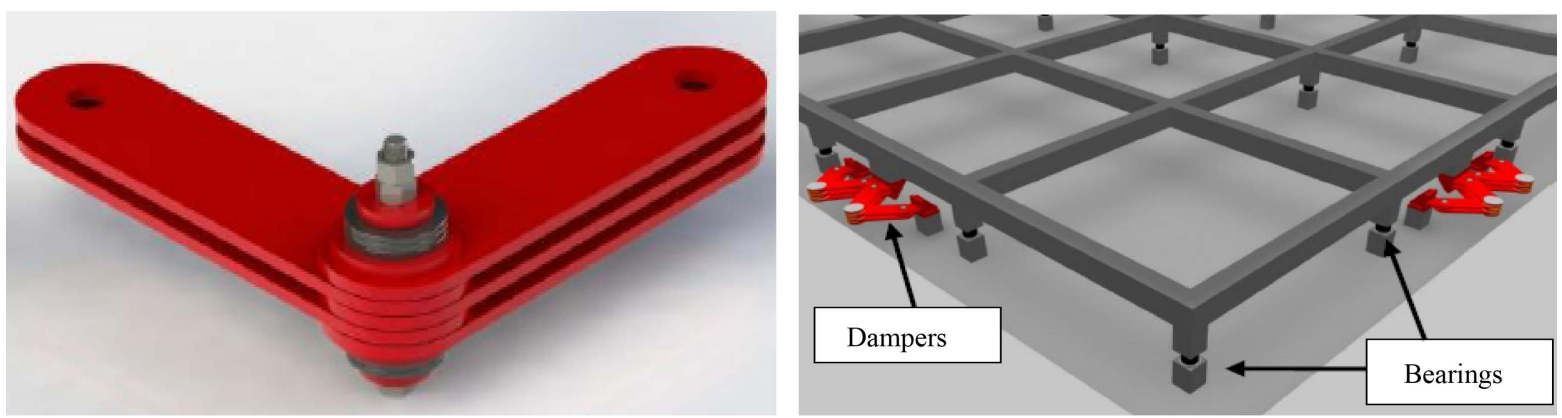

Figure 6. Damper (FD) and place it in the construction within insulation system [4].

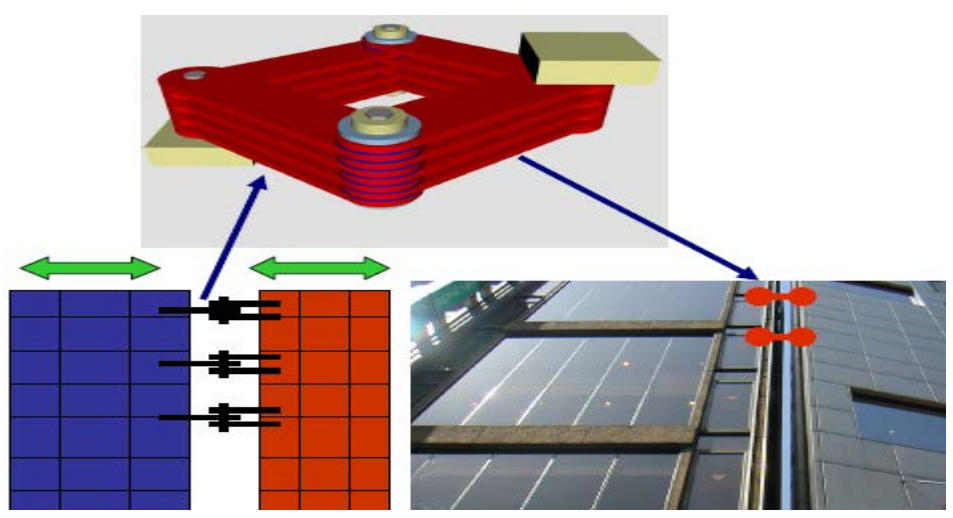

Figure 7. It shows the use friction damper to solve the problem of the nearby distance between buildings.

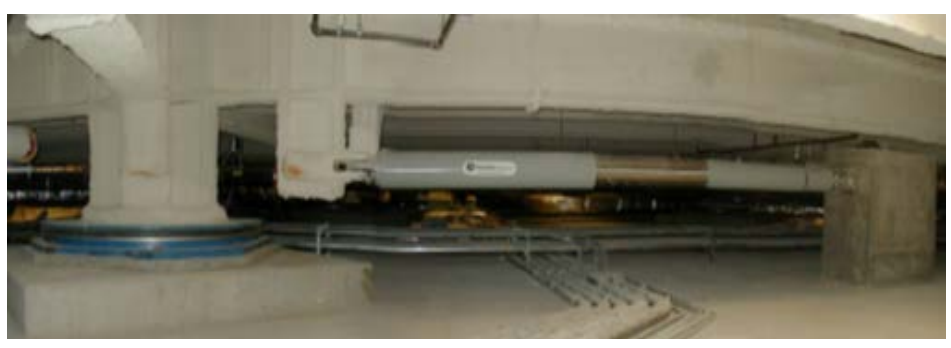

Figure 8. It shows the use viscoelastic dampers as complementary to control displacement [8].
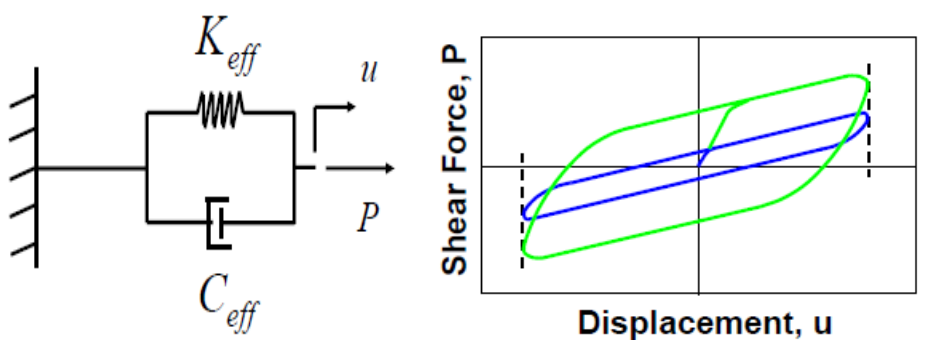

Figure 9. Mathematical model for rubber bearings (NRP) [11].

$$
P_{(t)}=k_{e f f} \cdot U_{(t)}+C_{e f f} \cdot \dot{U}_{(t)}
$$

The characterised strength $(Q)$ is effectively equal to the yield force $\left(F_{y}\right)$, of the lead plug. The yield stress of the lead plug is usually taken as being around $10 \mathrm{MPa}$. The effective stiffness $\left(k_{\text {eff }}\right)$ of the LPB, at a horizontal 
displacement $(D)$ being larger than the yield displacement $\left(D_{y}\right)$ may be defined in terms of the post-elastic stiffness $(K D$,$) and characteristic strength (Q)$, with the following equation (Figure 10) [11]:

$$
\begin{gathered}
K 2=\alpha K=\left(F-F_{Y}\right) /\left(D-D_{Y}\right) \quad \alpha=\frac{F_{Y}}{D_{Y}} \\
K_{\text {eff }}=\frac{F}{D}=\alpha K+\frac{Q}{D} \quad D \geq D_{Y}
\end{gathered}
$$

The energy dissipated for one cycle of sliding, with amplitude $(D)$ (Figure 10) can be estimated as:

$$
\begin{gathered}
W_{D}=4 Q\left(D-D_{Y}\right) \\
\text { IF } D \gg D_{Y}, \text { Then }: W_{D} \approx 4 Q D
\end{gathered}
$$

The effective percentage of critical damping provided by the isolator (Figure 10) can be obtained from:

$$
\varepsilon_{\text {eff }}=\frac{2 Q\left(D-D_{y}\right)}{\pi D(Q+\alpha K D)}
$$

\subsection{Modelling of Flat Sliding Bearings [1] [11]}

For Spherical Bearings:

$$
F(t)=\frac{W}{R} U(t)+\mu W \operatorname{sgn} \dot{U}
$$

Flat Bearings (Figure 11): $R \rightarrow \infty: F(t)=\mu W \sin \dot{U}$

where:

$\mu$ : Coefficient of friction for the sliding.

$W$ : Total seismic forces.

$\operatorname{sgn}(\dot{U}):$ Continued reference (Figure 11): $\operatorname{sgn}(\dot{U})= \begin{cases}-1 & \dot{U}<0 \\ +1 & \dot{U}>0 \\ 0 & \dot{U}=0\end{cases}$

- Bearings do NOT increase natural period of structure; rather they limit the shear force transferred into the superstructure (Figure 11) [11].

- Requires supplemental self-centering mechanism to prevent permanent isolation system displacement (Figure 11) [11].

\subsection{Rotation Friction Dampers (FD) [14]}

Modeling of friction damper as spring form (Plastic Wen link [14]) (Figure 12(b)),

The force in the Rotation Friction Dampers (FD) are determined in Figure 12(a) by the following equation:

$$
F=r k d+(1-r) y z
$$

$z$ : hysteretic variable where $-1 \leq z \leq 1$, the initial value of $z$ is zero.

$F$ : forced, $d$ : deformation, $k$ : Stiffness, $y$ : yield force, $r$ : yield ratio.

\subsection{Basic Concept of the Proposed New Damper [9]}

The schematic as well as basic principle of the proposed damper are shown in Figure 13 and Figure 14, respectively [9]. The damper (FD) has several steel arms one ends of which are linked each other by a bolt in order for them to rotate freely, and carefully manufactured disk friction materials are embedded in that link. By connecting both ends of these arms to the upper and lower structures, horizontal deformation of the girder is converted into the rotational motion of the link and disk. To be more precise, the horizontal force $\mathrm{F}$ in Figure 14 balances with the friction moment $\mathrm{M}$, depending on the moment arm length $\mathrm{L}$. 


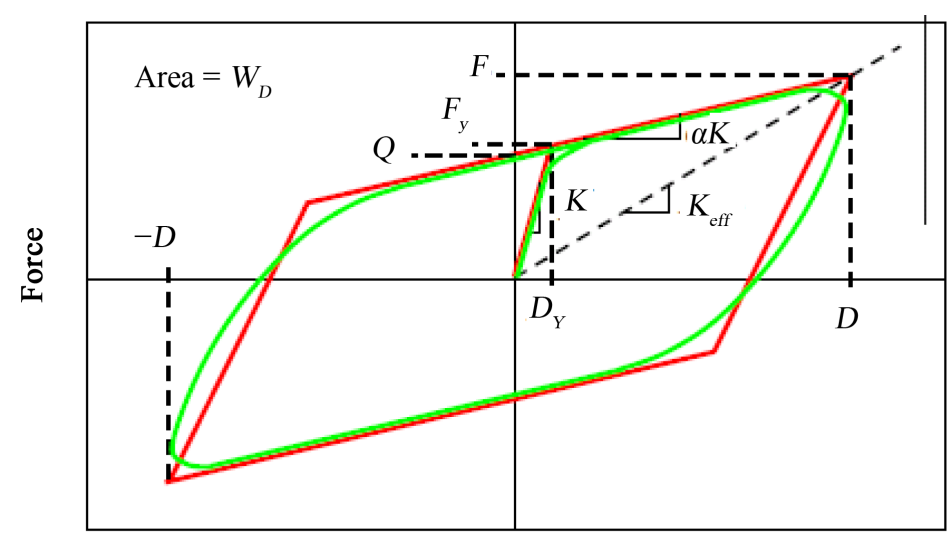

Displacement

Figure 10. Hysteresis loop of rubber bearings [11].
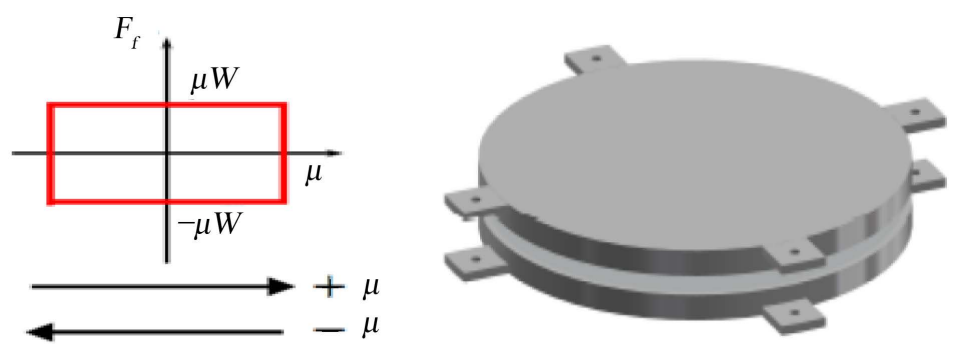

Figure 11. Response flat sliding, response friction [11].

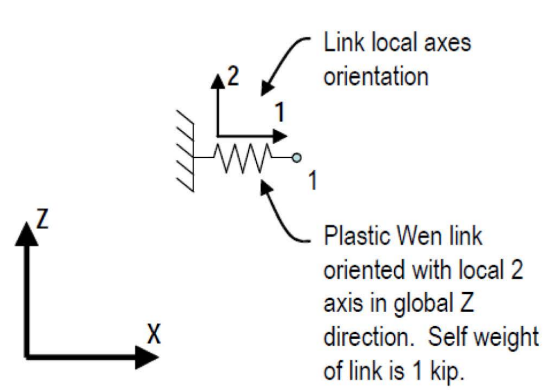

(a)

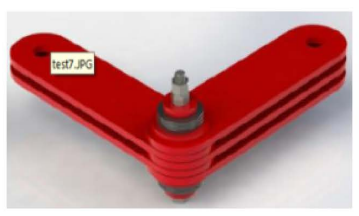

of link is 1 kip.

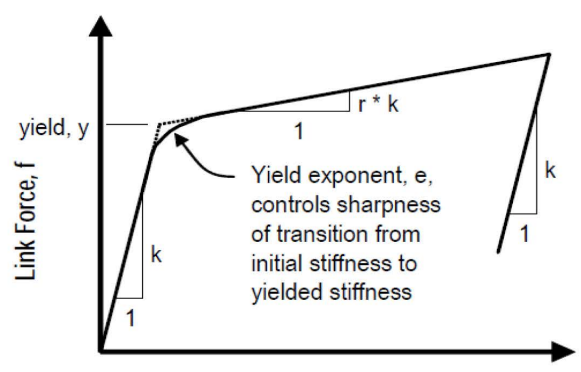

Link Deformation, d

(b)

Figure 12. (a) The power relationship-transmission of the damper (FD); (b) The form and damper model [14].

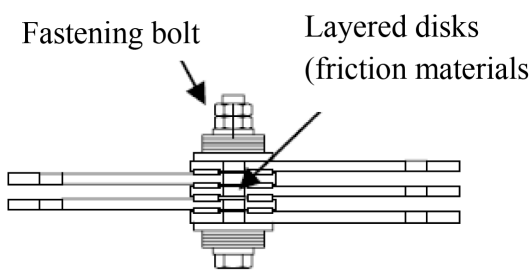

Direc. of motion

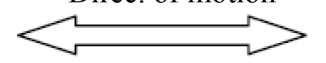

(a) Elevation

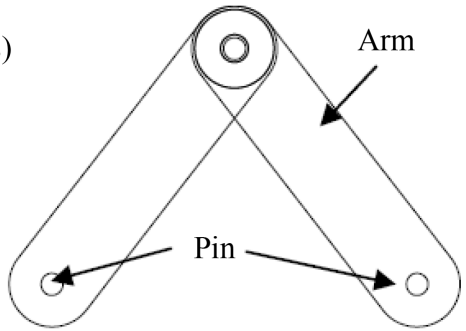

(b) Top view

Figure 13. Schematic of the proposed damper [9]. 


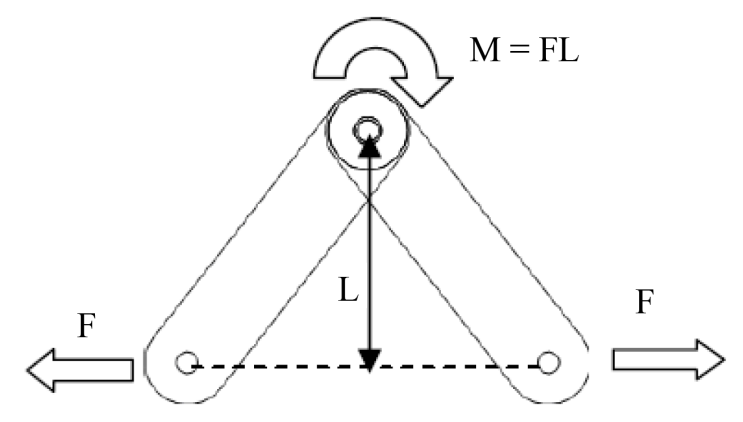

Figure 14. Basic mechanism of the damper [9].

\section{Base Isolation System for Buildings}

Combination of rotation friction dampers, rubber bearings and flat sliders (Figure 15):

\subsection{Analysis}

The free vibration analysis, time history earthquake analysis is performed by using SAP 2000 software, the natural and mode shapes of the building are obtained from the free vibration analysis, from the time history analysis, the time dependent dynamic responses of the building for the whole duration of the earthquake excitation, the base shear, displacement, shears, moments and axial loads of the elements at various amounts of earthquake ground motions have been determined.

The understanding of seismic behavior of building structure by isolators has been done by four analysis methods such as - (without use of seismic isolation, structure foundations of traditional) (Fix), use isolation methods (rubber and sliding isolators) (LRB + FSB), (rubber, sliding with rotation friction dampers at the base of the building) (FD + FSB + LRB) Figure 15 and Figure 16(b), and (rubber, sliding with rotation friction dampers at the ground floor level) (FD1 + FSB + LRB) Figure 16(c).

El Centro earthquake is selected for Time History analysis to understand the seismic performance of the case study building.

We will study the building several heights (eight-story, twelve-story, sixteen floors, and twenty-story).

\subsection{Material and Structural Properties}

The studied construction of reinforced concrete (Figure 16), and higher multiple floor equals $3 \mathrm{~m}$, columns dimensions: $50 \times 50 \mathrm{~cm}$, dimensions Beams: $70 \times 30 \mathrm{~cm}$, Solid slab thickness $15 \mathrm{~cm}$, loads of coverage: $3 \mathrm{KN} / \mathrm{m}^{2}$, liveloads: $3 \mathrm{KN} / \mathrm{m}^{2}$.

The required material properties like mass, weight density, modulus of elasticity shear modulus and design values of the material used can be modified as per requirements or default values can be adopted Beams and column members have been defined as "frame elements" with the appropriate dimensions and reinforcement. Soil structure interaction has not been considered. Slabs are defined as area elements having the properties of shell elements with the required thickness.

In our case, the slabs have been modeled as rigid diaphragms and in this connection, the center of rigidity (mass) and center of gravity of building is considered same in order to neglect the effect of torsion.

\subsection{The First Case Building Height 8 Storied}

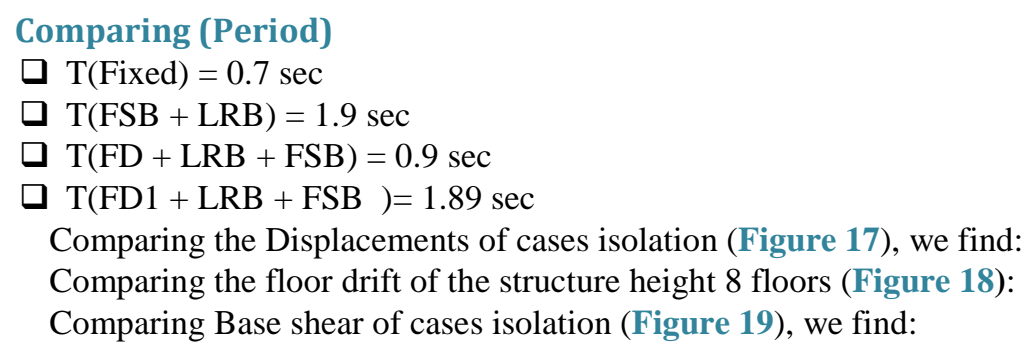



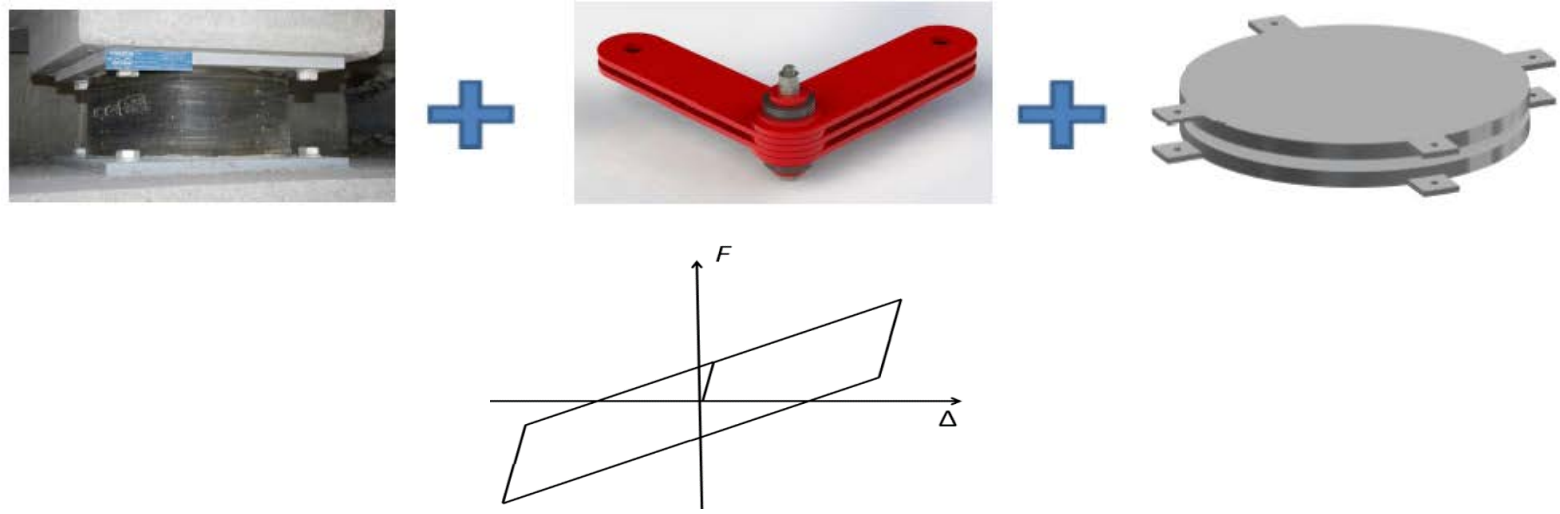

Figure 15. Devices combined hysteresis loop.

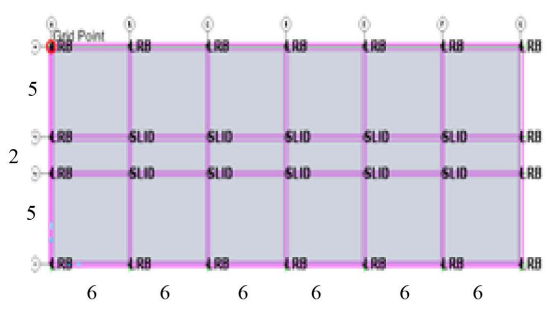

(a)

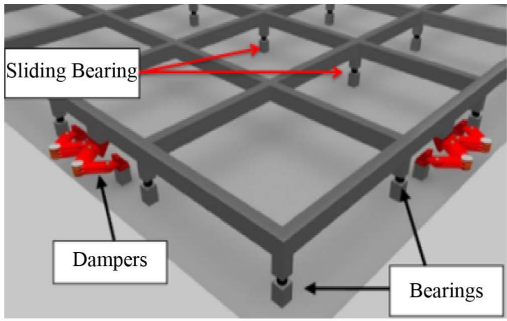

(b)

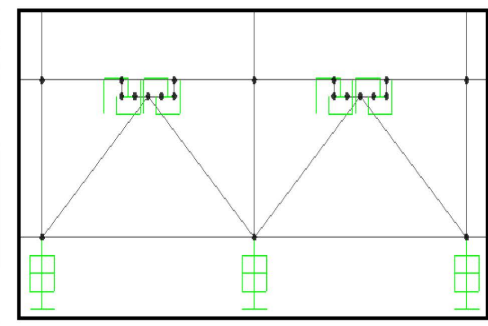

(c)

Figure 16. (a) Plan view of symmetrical building shown by the distribution of seismic isolators and dampers; (b) The rotation friction dampers at the base of the building (FD); (c) The rotation friction dampers at the ground floor level (FD1).

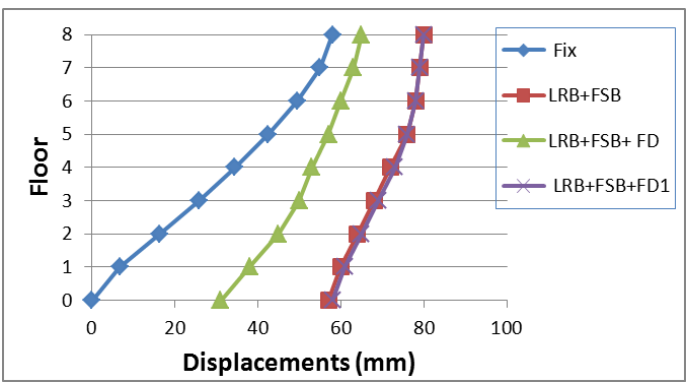

Figure 17. Floors displacements of the structure height 8 floors.

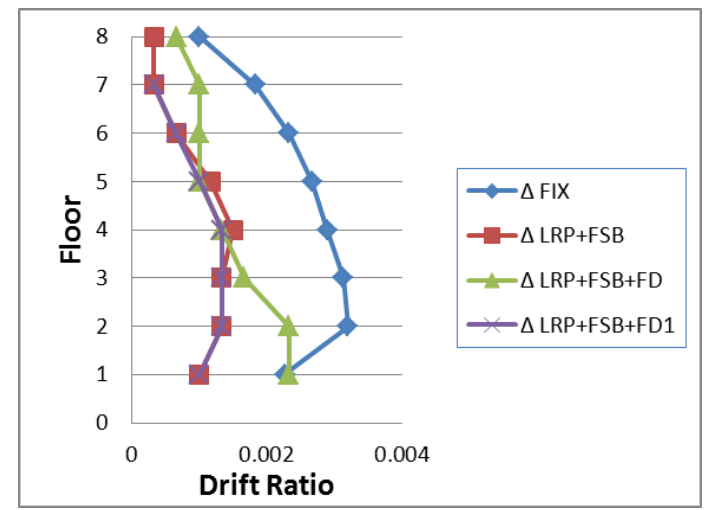

Figure 18. Floor drift ratio of the structure height 8 floors. 
We have the follow-up analysis of the structure of the higher (12-16-20) floor and compare the results in terms of period (Table 1), base shear (Table 1), displacements (Table 2), and drift (Table 3), and collected results in following tables:

Comparing the results of the use of hybrid isolation system (LRB + FSB) with friction damper (FD) on the base shear (Figure 20), displacements (Figure 21), and drift of the structure (Figure 22), with increasing the height of the structure and compare it with the rubber bearings isolated structure from a previous study [10]:

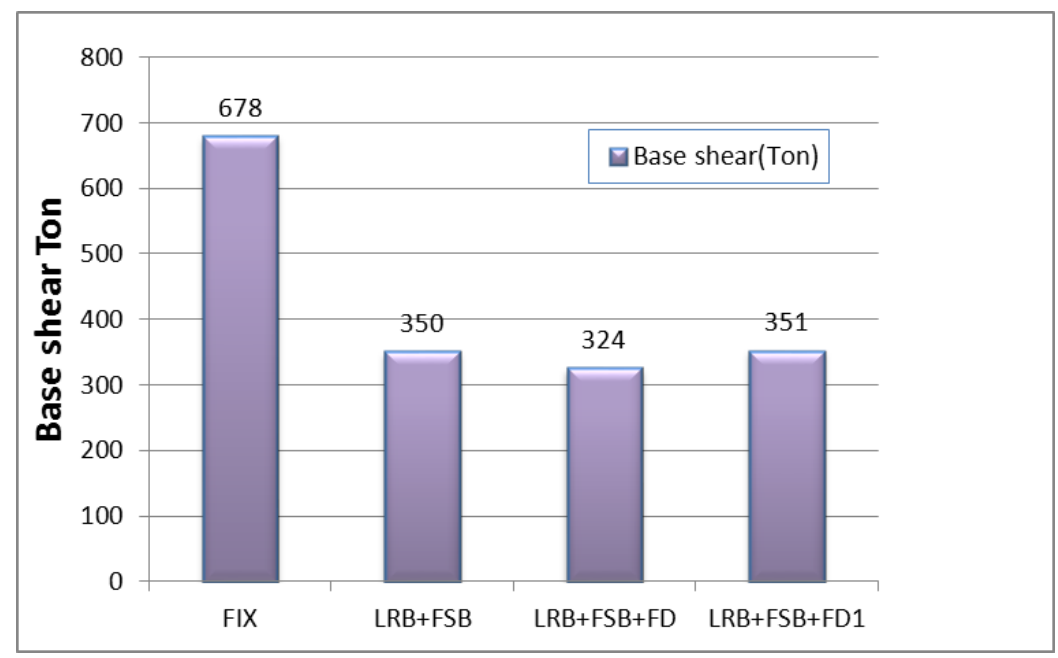

Figure 19. Base shear of the structure height 8 floors.

Table 1. It demonstrates period, base shear, the amount of reduction of base shear and drift for isolation cases.

\begin{tabular}{|c|c|c|c|c|c|c|c|c|c|c|}
\hline \multirow{2}{*}{ 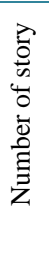 } & \multicolumn{2}{|c|}{ Fixed base } & \multicolumn{2}{|c|}{$\begin{array}{l}\text { Rubber and sliding } \\
\text { isolators (LRB, FSB) }\end{array}$} & \multicolumn{2}{|c|}{$\begin{array}{l}\text { Rubber, sliding with } \\
\text { rotation friction dampers } \\
\text { at the base of the } \\
\text { building (FD, FSB, } \\
\text { LRB) }\end{array}$} & \multicolumn{2}{|c|}{$\begin{array}{l}\text { Rubber, sliding with } \\
\text { rotation friction } \\
\text { dampers at the } \\
\text { ground floor level } \\
\text { (FD1, FSB, LRB) }\end{array}$} & \multirow{2}{*}{$\begin{array}{l}\text { The amount of } \\
\text { reduction of base } \\
\text { shear as a result } \\
\text { of isolation } \\
\text { structure \% }\end{array}$} & \multirow{2}{*}{$\begin{array}{c}\text { The amount of } \\
\text { reduction drift } \\
\text { as a result of } \\
\text { isolation } \\
\text { structure \% }\end{array}$} \\
\hline & $\begin{array}{l}\text { Time } \\
\text { period } \\
\text { (sec.) }\end{array}$ & $\begin{array}{l}\text { Base shear } \\
\text { (ton) }\end{array}$ & $\begin{array}{l}\text { Time } \\
\text { period } \\
\text { (sec.) }\end{array}$ & $\begin{array}{l}\text { Base shear } \\
\text { (ton) }\end{array}$ & $\begin{array}{l}\text { Time period } \\
\text { (sec.) }\end{array}$ & $\begin{array}{l}\text { Base shear } \\
\quad \text { (ton) }\end{array}$ & $\begin{array}{l}\text { Time period } \\
\text { (sec.) }\end{array}$ & $\begin{array}{l}\text { Base shear } \\
\text { (ton) }\end{array}$ & & \\
\hline 8 & 0.7 & 655 & 1.9 & 350 & 0.9 & 324 & 1.89 & 351 & $47 \%$ & $65 \%$ \\
\hline 12 & 1.1 & 883 & 2.37 & 341 & 1.41 & 311 & 2.36 & 345 & $61 \%$ & $74 \%$ \\
\hline 16 & 1.5 & 497 & 2.94 & 466 & 1.83 & 325 & 2.93 & 458 & $6 \%$ & $28 \%$ \\
\hline 20 & 2 & 564 & 3.31 & 582 & 2.3 & 390 & 3.31 & 581 & $-3 \%$ & $13 \%$ \\
\hline
\end{tabular}

Table 2. It shows max, min displacements to the traditional structure after isolated by hybrid isolation system with the addition of seismic dampers.

\begin{tabular}{|c|c|c|c|c|c|}
\hline 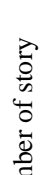 & $\begin{array}{l}\text { Rubber and sliding } \\
\text { isolators (LRB, FSB) }\end{array}$ & $\begin{array}{l}\text { Rubber, sliding with } \\
\text { rotation friction } \\
\text { dampers at the base } \\
\text { of the building } \\
\text { (FD, FSB, LRB) }\end{array}$ & $\begin{array}{l}\text { Rubber, sliding with } \\
\text { rotation friction } \\
\text { dampers at the } \\
\text { ground floor level } \\
\text { (FD1, FSB, LRB) }\end{array}$ & $\begin{array}{l}\text { Reduction } \\
\text { displacements } \\
\text { the result of adding } \\
\text { rotation friction damp } \\
\text { ers at the base of the }\end{array}$ & $\begin{array}{l}\text { Reduction } \\
\text { displacements } \\
\text { the result of adding } \\
\text { rotation friction } \\
\text { dampers at the }\end{array}$ \\
\hline 之 & $\begin{array}{c}\text { Max, min } \\
\text { displacements (mm) }\end{array}$ & $\begin{array}{c}\text { Max, min } \\
\text { displacements (mm) }\end{array}$ & $\begin{array}{c}\text { Max, min } \\
\text { displacements (mm) }\end{array}$ & $\begin{array}{c}\text { isolated structure } \\
\%\end{array}$ & $\begin{array}{l}\text { on isolated } \\
\text { structure \% }\end{array}$ \\
\hline 8 & $52-75$ & $32-61$ & $53-71$ & $28 \%$ & Almost without change \\
\hline 12 & $40-67$ & $25-62$ & $40-67$ & $19 \%$ & Almost without change \\
\hline 16 & $97-127$ & $30-91$ & $77-121$ & $46 \%$ & $11 \%$ \\
\hline 20 & $129-213$ & $39-152$ & $130-211$ & $44 \%$ & Almost without change \\
\hline
\end{tabular}


Table 3. It shows effect on drift as a result of adding rotation friction dampers hybrid isolation system.

\begin{tabular}{|c|c|c|}
\hline 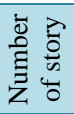 & $\begin{array}{c}\text { Effect on drift as a result of adding rotation friction } \\
\text { dampers at the base of the building } \\
\text { on isolated structure \% }\end{array}$ & $\begin{array}{c}\text { Effect on drift as a result of adding rotation friction dampers } \\
\text { at the ground floor level on } \\
\text { isolated structure } \%\end{array}$ \\
\hline 8 & Increase (48\%) & Almost without change \\
\hline 12 & Increase (18\%) & Reduction (13\%) \\
\hline 16 & Increase (27\%) & Reduction (8\%) \\
\hline 20 & Increase (15\%) & Reduction (15\%) \\
\hline
\end{tabular}

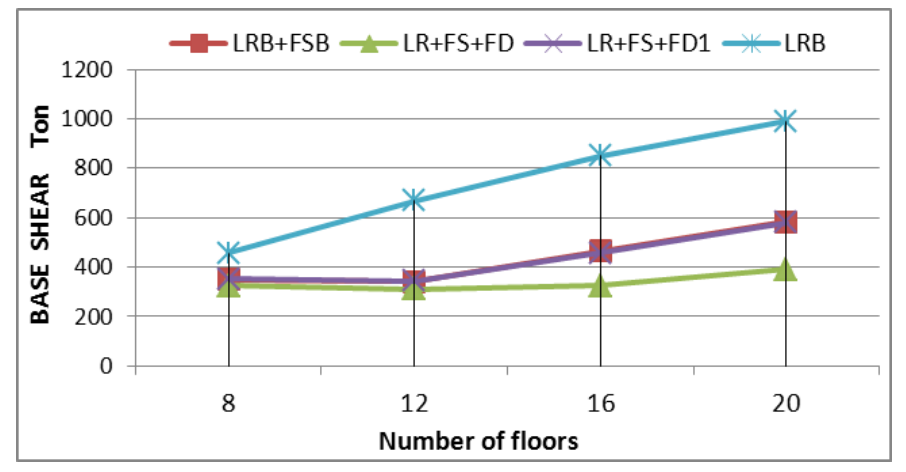

Figure 20. It shows the change in base shear with increasing the height of the structure to cases of isolation (LRB, FSB, FD, FD1).

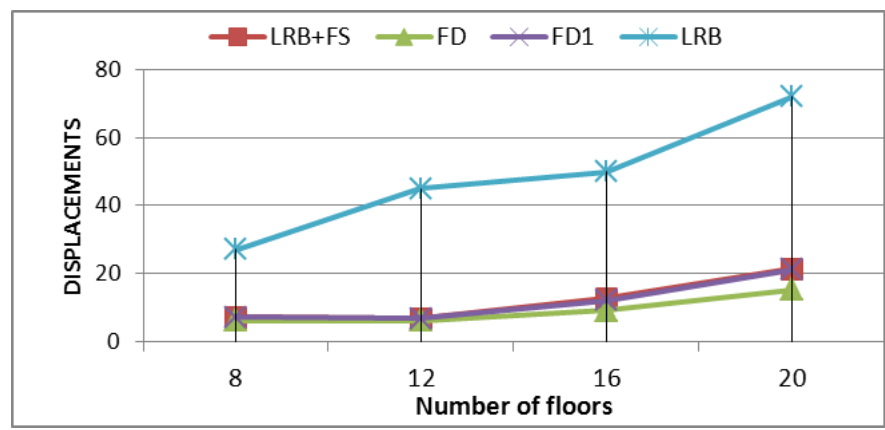

Figure 21. It shows the displacements with increasing the height of the structure to cases of isolation (Fix, LRB, FSB, FD, FD1).

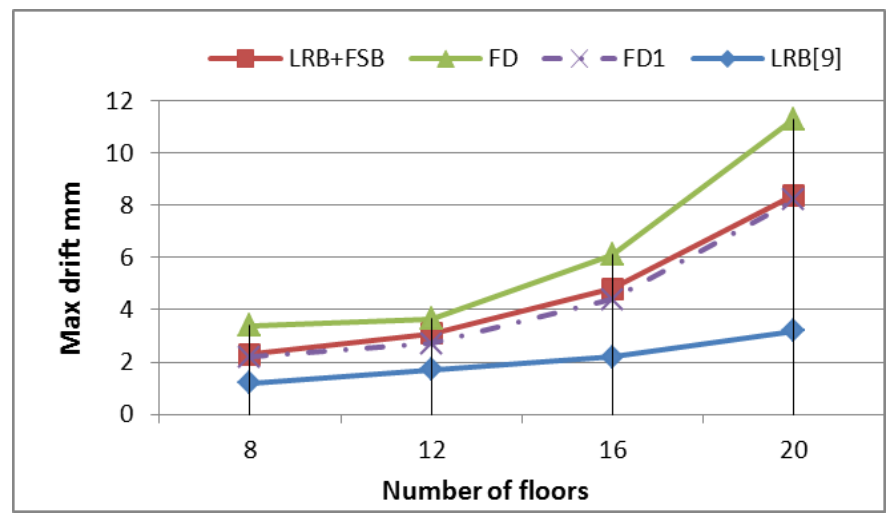

Figure 22. It shows max drift with increasing the height of the structure to cases of isolation (Fix, LRB, FSB, FD, FD1). 


\section{Results}

1) The results of displacement show that the displacements are increased with the period and with the story height in the base isolated building.

2) The effectiveness of hybrid isolation system (LRB + FSB) in reducing the base shear and drift of the structure isolated decreases with increased flexibility of structure.

3) Using hybrid isolation system (LRB + FSB) with the addition of rotation friction dampers (FD) at the base of the structure, has had a significant impact on improving the performance of isolated structure by hybrid isolation system (LRB + FSB), in terms of reducing displacements, base shear with increased height, but has had a negative impact on the drift, which lead to an increase in the drift with the increased flexibility structure.

4) Using hybrid isolation system (LRB + FSB) with the addition of rotation friction dampers (FD) at the ground floor level is not effective, and does not lead to any improvement in the performance of structure isolated by (LRB + FSB), in terms of displacements or base shear, while it has a positive effect on reducing the drift with the increased flexibility structure.

\section{References}

[1] Trever, K. (2001) Base Isolation of Structure. Design Guideline Holmes Consulting Group.

[2] Naeim, F. and Kelly, J. (1996) Design of Seismic Isolated Structures. Wiley, New York.

[3] Jangid, R.S. (2004) Optimum Friction Pendulum System for Near-Fault Motions. Engineering Structures.

[4] Leif, O., Mualla, I.H. and Iwai, Y. (2004) Seismic Isolation with a New Friction-Viscoelastic Damping System. 13th World Conference on Earthquake Engineering, Vancouver, 1-6 August 2004.

[5] Earthquake Protection Systems (2003) Technical Characteristics of Friction Pendulum Bearings. Vallejo, California.

[6] Tsai, C.S., Chiang, T.C. and Chen, B.J., Chen, J.C., Ed. (2003) Seismic Behavior of MFPS Isolated Structure: Seismic Engineering 2003. ASME, 73-79.

[7] Fenz, D.M. and Constantine, M.C. (2005) Behavior of the Double Concave Friction Pendulum Bearing. Submitted for Review and Possible Publication in Earthquake Engineering and Structural Dynamics.

[8] Morgan, T.A. and Mahin, S.A. (2011) The Use of Base Isolation Systems to Achieve Complex Seismic Performance Objectives. Pacific Earthquake Engineering Research Center College of Engineering University of California, Berkele.

[9] Toyooka, A., Himeno, T., Hishijima, Y., Iemura, H. and Mualla, I. (2008) Verification Tests of the Dynamic Behavior of the Novel Friction-Based Rotational Damper Using Shaking Table. The 14th World Conference on Earthquake Engineering, 12-17 October 2008, Beijing.

[10] Thaer, T. (2011) The Behavior of Seismically Isolated Buildings Using Rubber Bearing. Master, the Higher Institute of Seismic Studies and Research, University of Damascus.

[11] Symans, M.D. (2010) Design Examples Seismic Isolation. Instructional Material Complementing FEMA 451.

[12] Shirule, P.A., Jagtap, L.P., Sonawane, K.R., Patil, T.D., Jadwanir, N. and Sonar, S.K. (2012) Time History Analysis of Base Isolated Multi-Storied Building. International Journal of Earth Sciences and Engineering, 5, 809-816.

[13] Wang, Y.-P. (2009) Fundamentals of Seismic Base Isolation. International Training Programs for Seismic Design of Building Structures Hosted by National Center for Research on Earthquake Engineering Sponsored by Department of International Programs, National Science Council.

[14] SAP2000, Software Verification.

[15] Andrade, L. and Tuxworth, J. (2009) Seismic Protection of Structures with Modern Base Isolation Technologies. Paper 7a-3, Concrete Solutions.

[16] (2003) Structural Protection Systems. MAURER Seismic Isolation Systems with Lead Rubber Bearings (LRB). SPS/ 02.05. 2003. 
Scientific Research Publishing (SCIRP) is one of the largest Open Access journal publishers. It is currently publishing more than 200 open access, online, peer-reviewed journals covering a wide range of academic disciplines. SCIRP serves the worldwide academic communities and contributes to the progress and application of science with its publication.

Other selected journals from SCIRP are listed as below. Submit your manuscript to us via either submit@scirp.org or Online Submission Portal.
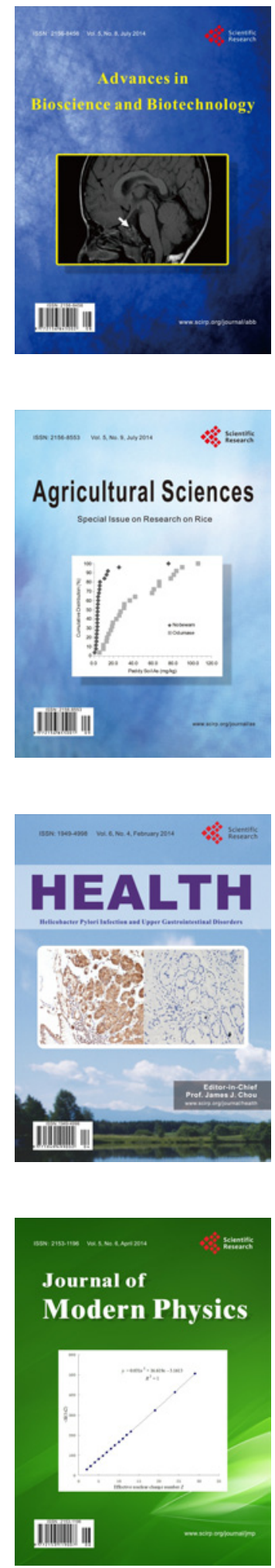
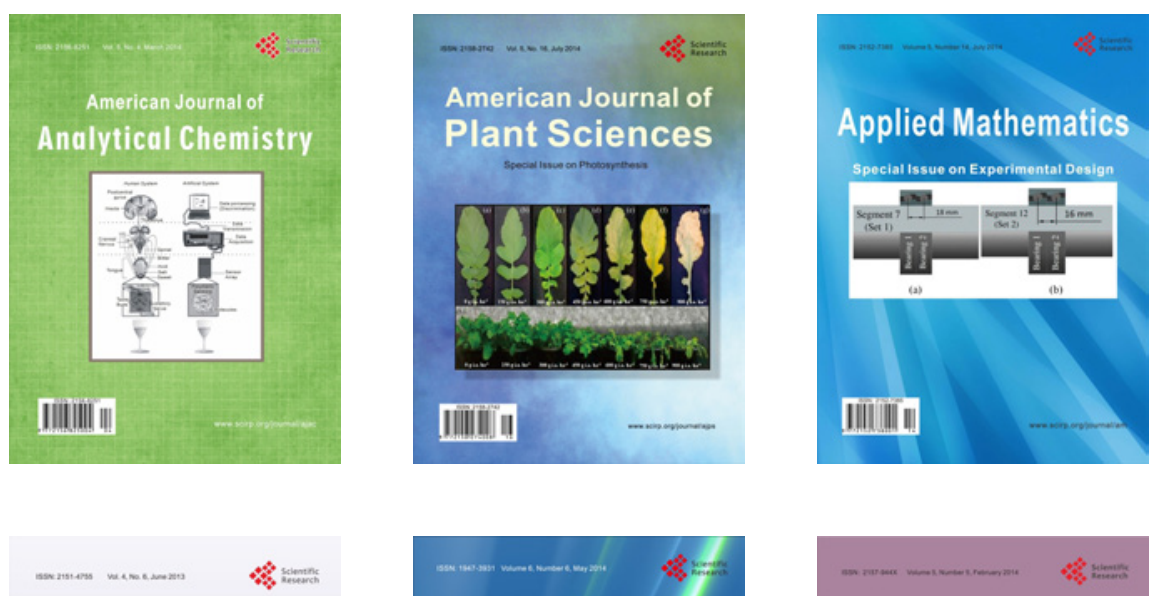

Creative Education
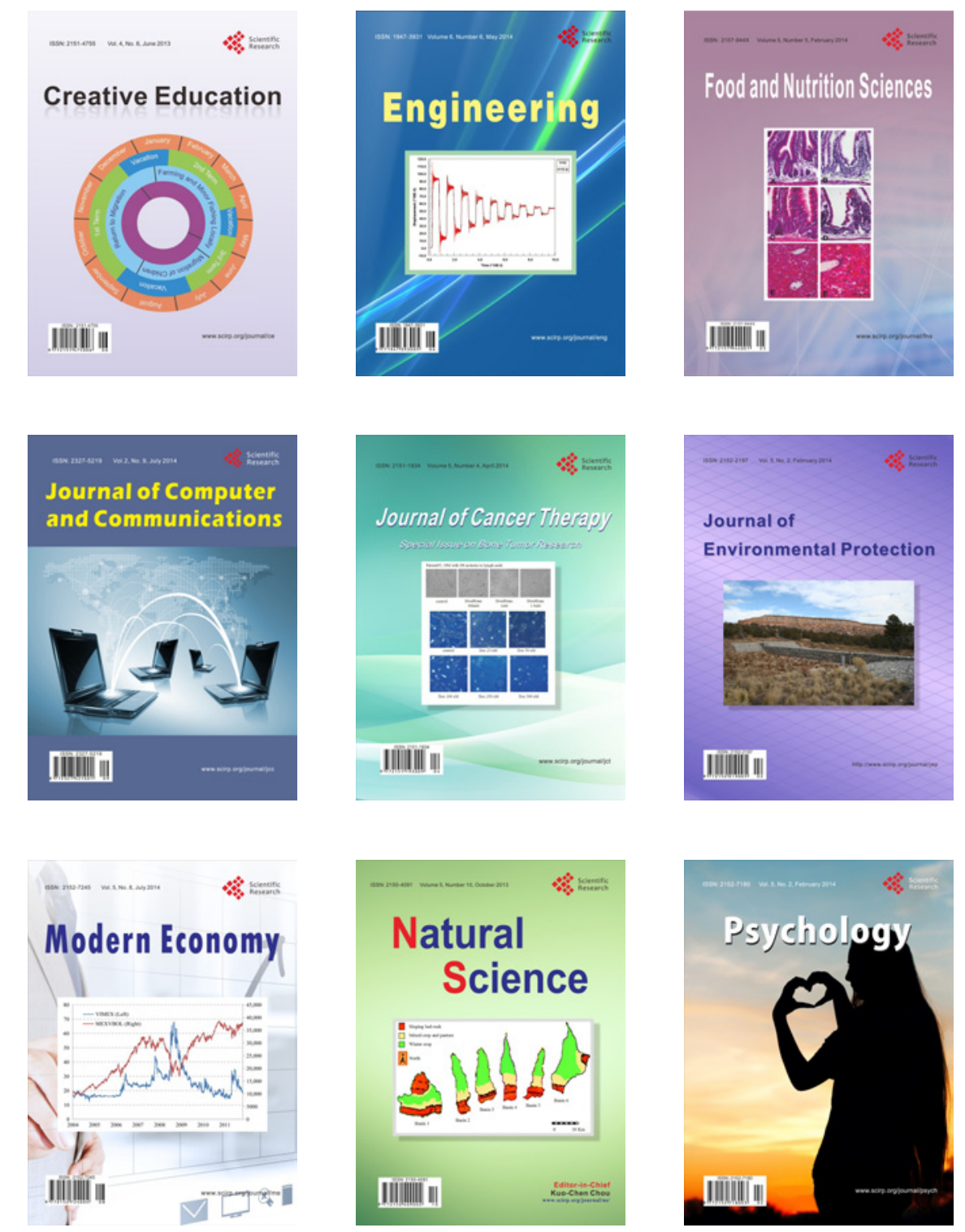